\title{
Kofi Yakpo
}

\section{Wayward daughter: Language contact in the emergence of Pichi (Equatorial Guinea)}

\begin{abstract}
Pichi is an Afro-Caribbean English Lexifier Creole (AEC) spoken by some 150,000 people on the island of Bioko, Equatorial Guinea. Pichi is an offshoot of Krio (Sierra Leone) and shares many characteristics with its West African sister languages. However, insulation from English and Krio, extensive contact and hybridization with Spanish, language shift involving the Bantu language Bubi, as well as koineization through the prolonged coexistence of Pichi with closely-related languages like Nigerian Pidgin and Cameroonian Pidgin have given the language a character distinct from that of the other English Lexifier creoles of the region. The study of Pichi and its comparison with other West African AECs therefore offers fresh insights into the role that language contact has played in the differentiation of the Afro-Caribbean English lexifier Creoles.
\end{abstract}

Keywords: multilingual, creolization, hispanic, substrate, language change

Kofi Yakpo: The University of Hong Kong. E-mail: kofi@hku.hk

\section{Introduction}

Pichi is a direct offshoot of the Krio language of Sierra Leone. The ancestor of the Afro-Caribbean English Lexifier Creole, Pichi, first arrived in Bioko (cf. Map 1), then known under its colonial designation of Fernando Po, with African settlers from Freetown, Sierra Leone in 1827 (Fyfe 1962: 165). The island of Bioko is one of three geographical entities that make up the nation of Equatorial Guinea, the second being Annobón island, and the third being Río Muni, on the African continent. Its speakers refer to their language by the name of "Pichi" or "Pichinglis" (derived from the etymons "Pidgin" and "Pidgin English"), but some older speakers still use the name "Krio" for their language. The xenonym "Fernando Po Creole English" is used in some sources (e.g. in the Ethnologue entry on Equatorial Guinea, cf. Lewis, Simons and Fennig 2013), and the language's ISO code "fpe" is derived from it.

Pichi is primarily spoken in the Equato-Guinean capital Malabo, located on Bioko island, and is used as a lingua franca throughout the entire island. There are no language-specific census data on Equatorial Guinea. From my own 


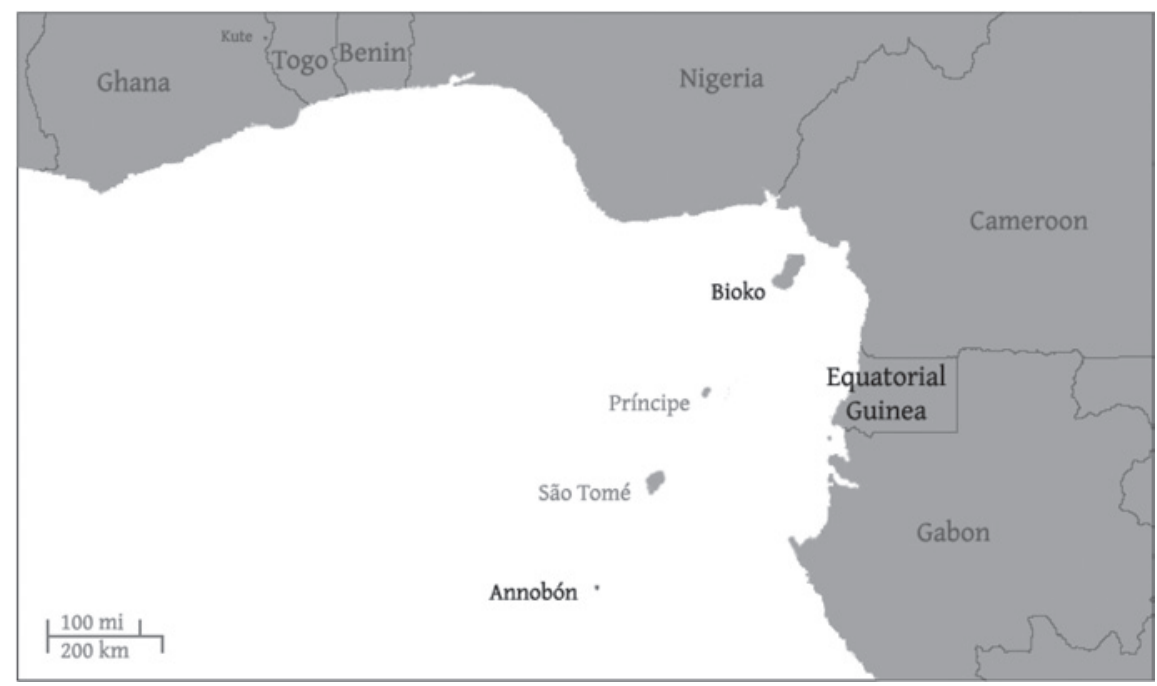

Map 1: Continental and insular Equatorial Guinea (Yakpo 2009b: 2)

extrapolations, it is probably safe to assume that at least 70 percent of the population of Bioko island, hence more than 150,000 speakers use Pichi regularly as a primary or secondary language. In terms of speaker numbers, this makes Pichi the smallest language of the African Branch of the family of Afro-Caribbean English Lexifier Creoles after Aku (spoken in The Gambia). Yakpo 2009b and 2010 contain an extensive description of the phonology and grammar of Pichi in English and Spanish respectively.

In the following, I will show that in terms of its lexicon and grammar, Pichi is a typical representative of the family of languages referred to in the literature as English-based Afro-American (Alleyne 1980), Atlantic Anglophone Creoles (Hancock 1986, 1987), Atlantic English-based Creoles (McWhorter 1997), Englishbased/English-lexicon/English-lexifier Atlantic Creoles (e.g. Baker 1999; Baker \& Huber 2001; Holm 2000) and Afro-Caribbean English Lexifier Creoles (Faraclas 2004; Yakpo 2012). In terms of speaker numbers and geographical distribution, the trans-Atlantic chain of often mutually intelligible Afro-Caribbean English Lexifier Creoles (henceforth AECs) must be counted as one of the largest (dia-)lectal continua of the Western hemisphere. ${ }^{1}$

1 This can be extrapolated from speaker numbers in the largest AEC-speaking countries, i.e. Nigeria, 80 M (Ihemere 2006), Ghana 5 M (Huber 2012); Sierra Leone 5 M (Finney 2011); Jamaica $\sim 3$ M (Farquharson, p.c.). 
Within the family, Pichi is most directly related to Krio of Sierra Leone. However, direct contact between Pichi and its parent Krio, as well as its English lexifier was interrupted in the mid-19 ${ }^{\text {th }}$ century, when Spanish came to replace English as the colonial language and superstrate, and regular trading contacts between Sierra Leone and Bioko ground to a halt. Further, Pichi is the only African AEC that has a predominantly Bantu adstrate (and substrate for shifters to Pichi), namely Bubi (Narrow Bantu, A31, ISO code "bvb”). I argue that the early separation of Pichi from Krio, its insulation from the normalizing influence of English as a superstrate language, extensive contact with Spanish, language shift from Bubi to Pichi, and koineization involving other West African AECs have allowed Pichi to develop relatively exotic features compared to other languages of the family. The study of Pichi therefore offers a unique opportunity for comparing the impact of contact with lexifier superstrates, non-lexifier superstrates, substrates and adstrates on the differentiation of the African AECs.

This paper is organized as follows: In Section 2, I provide an overview of the origins and socio-history of Pichi. In Section 3, I dicuss the genealogical classification of Pichi in a comparative perspective. Sections 4, 5 and 6 address the particular trajectory of Pichi with respect to language contact with Spanish, language shift from the Bubi language and koineization involving other African AEC varieties. In Section 7, I conclude that the specific socio-history of Bioko has made Pichi a wayward daughter within the African branch of the AEC family. The highly distinct character of present-day Pichi sharply sets it apart from its West African sister languages.

All linguistic examples and forms provided without references stem from a diverse corpus consisting of naturalistic and elicited speech of approximately 60,000 words collected by the present author in West Africa between 2003 and 2011.

\section{Socio-historical overview}

In 1827, the town of Port Clarence (later renamed to Santa Isabela under Spanish rule, then Malabo after independence in 1968) was founded by the British on the island of Fernando Po, as Bioko was then called. Krio and Kru people from Freetown, Sierra Leone, constituted the largest group of Africans in the first group of settlers (del Molino 1993: 116). The British had enlisted Africans from Freetown to join the colonial enterprise because they needed their artisanal skills for construction work in the town, and their English literacy and numeracy skills for administrative work. Krios of Sierra Leonean origin came to play a dominant role in the new society of $19^{\text {th }}$ century Port Clarence. They provided the cultural and 
linguistic models for the growing African population of diverse origins (García Cantús 2006: 116-118), which came to be collectively known by the ethnonym "Fernandinos" (< Fernando Po) (cf. Lynn 1984). As a consequence, Krio was not only maintained as the primary medium of communication in the town itself, it was also spread throughout Fernando Po by Fernandino traders who first acted as middlemen in the palm oil trade with the Bubi (Lynn 1984: 267; del Molino 1993: 116), then engineered and financed the transformation of Fernando Po into the most productive cocoa plantation economy of West Africa in the late $19^{\text {th }}$ century. Until that time, regular ship connections between Freetown and Fernando Po ensured a continuous flow of people, goods and cultural patterns from Sierra Leone and reinforced the position of Krio (del Molino 1993: 62-64). However, Spanish colonial rule began to be rigorously imposed from 1858 onwards and the Kriospeaking élite began to adapt by appropriating Spanish cultural and linguistic norms, with Spanish having replaced English as the community's prestige code by the early $20^{\text {th }}$ century (Trinidad Morgades, p.c.).

The Spanish colonial regime further expanded the cocoa plantation economy and turned the island into the destination of a massive movement of labour migration (Sundiata 1990: 30). At least 7000 Kru men from Liberia were brought to Bioko between 1914 to 1927 (Sundiata 1990: 45). The influx of Nigerian labourers was even more important. By the 1960s, 85,000 Nigerian farmhands laboured on the cocoa plantations of Fernando Po, all of whom were from southern Nigeria (Lipski 1992: 40). Migrant workers became victims of state repression after independence, a situation that culminated in the wholesale expulsion of all plantation workers during the dictatorial regime of Macías Nguema in the 1970s. In the contact scenario of which Pichi forms a part, one additional factor cannot be underestimated in its relevance. The Fernandino community of Bioko has seen a steady decline in relative number through emigration, ethnic fusion, and the loss of economic and political power throughout the $20^{\text {th }}$ century, and in particular since the independence of Equatorial Guinea in 1968. This decline has been translated into a linguistic reality. The Fernandinos no longer have the normalising power they may have held over Pichi before. This is aptly reflected in the name of the language itself. While older members of the Fernandino community might still refer to their language as "Krio", the average younger speaker of any cultural background will refer to the English Lexifier Creole of Bioko as "Pichi” or "Pichinglis".

Pichi today remains vibrant in Bioko and continues expanding at the expense of Bubi. At the same time, Equatorial Guinea is today traversing the most profound economic and social changes since the colonial era. The country has become a major oil-producer of Africa. The capital Malabo, the island of Bioko and the mainland part of the country are attracting tens of thousands of migrant 
workers from other AEC-speaking West African countries in search of economic opportunity. At the same time, internal migration from Río Muni (mainland Equatorial Guinea) to Bioko island has significantly raised the number of speakers of the nation's numerically dominant Bantu language Fang on the island. Equally, the considerable expansion of Spanish-medium education is strengthening the role of the former colonial language. It remains to be seen how the status and linguistic system of Pichi are affected by these profound socioeconomic transformations.

\section{Comparative perspectives}

A comparison of the phonology, grammar and lexicon of Krio and Pichi reveals striking similarities between the two languages (cf. D’jačkov 1981, Fyle and Jones 1980, Hancock 1976 for grammatical overviews of Krio). There is sufficient linguistic and historical evidence to suggest that Pichi, Krio and its Gambian descendant Aku also have at least partially common origins with Nigerian Pidgin, Cameroonian Pidgin and Ghanaian Pidgin English (cf. e.g. Huber 1999). The majority of roots in the lexicon of Pichi are derived from Krio. Krio in turn, derives most of its lexicon from English lexical sources. Compare the English-derived words in Pichi and Krio shown in Table $1 .^{2}$

Table 2 presents the lexical similarity of a select number of creoles and non-creoles. The data was generated on the basis of the Automated Similarity

Table 1: Pichi and Krio cognates

\begin{tabular}{llll}
\hline Pichi & Krio & Etymology & Gloss \\
\hline finis & finish & < finish & 'to finish' \\
tròwé & tròwé & <throw away & 'throw away; pour' \\
human & uman & < woman & 'woman' \\
da(n) & da(t) & <that & 'that' \\
pàntáp & pàntáp & < upon top & 'on; top' \\
\hline
\end{tabular}

2 Tones are graphicized in the following way: Monosyllables and penultimate syllables always bear a high tone if they bear no tone accent (e.g. go [gó] 'go'; waka [wákà] 'walk'). When a high tone occurs elsewhere in a multisyllabic word it is marked so by an acute accent (e.g. nyoní [njjoní] 'ant'). Low-toned mono- or penultimate syllables always bear a grave accent (e.g. c̀f [èf] 'if'; mòtó [mòtó] 'car'). Syllables not covered by these notation rules are always low and remain unmarked. 
Table 2: Lexical similarity between AECs and other languages

\begin{tabular}{ll}
\hline Language & $\mathbf{0 0}$ = Lexical identity \\
\hline Pichi & 0.00 \\
Krio & 19.85 \\
Cameroonian Pidgin & 21.39 \\
Ghanaian Pidgin English & 28.34 \\
Nigerian Pidgin & 36.86 \\
Hawai'i Creole English & 37.24 \\
Jamaican Creole & 38.05 \\
Bislama & 38.36 \\
English & 42.05 \\
Saramaccan & 43.16 \\
Gullah & 44.34 \\
Limonese Creole & 45.48 \\
Tok Pisin & 45.88 \\
Sranan Tongo & 53.30 \\
Ndyuka & 55.02 \\
Berbice Dutch Creole & 70.11 \\
Spanish & 94.20 \\
\hline
\end{tabular}

Judgment Program (ASJP) Database (Wichman et al. 2010; Wichman and Urban 2012). The computerised lexicostatistical analysis is based on a 40-item vocabulary list of diachronically maximally stable items extracted from the 100-item Swadesh list. The matrix includes representative English Lexifier Atlantic Creoles and for comparison, three Pacific Creoles (Bislama, Hawai'i Creole English and Tok Pisin), the Dutch Lexifier Creole Berbice Dutch as well as Pichi's superstrate language Spanish. The scale is from 0.00 (all lexical items in the 40-word list are shared between Pichi and the corresponding language) to 100 (no shared lexical item between Pichi and the corresponding language).

The order in Table 2 not only reflects the lexical affinity between Pichi and its closest relative Krio. It also shows the proximity of the other African members of the Atlantic English Lexifier Creoles and Pidgins, all of which occupy the first five rows. The ordering of languages also reveals a significant degree of lexical similarity between Pichi and the Caribbean English Lexifier Creoles. Lexical (and structural) similarities between the Afro-Caribbean and the Pacific have been attributed to a variety of factors. Among these figure the diffusion of lexical items through nautical jargons and pidgins during the early European colonial expansion (cf. e.g. Hancock 1987; Aceto 1999; Baker 1999; Baker and Huber 2001) as well as the diffusion of lexicon and grammatical features from the Atlantic to the Pacific through the substantial presence of Afro-Caribbean, African American 
and African seamen in the merchant and whaling fleets of the USA and Britain in the $18^{\text {th }}$ and $19^{\text {th }}$ centuries (Faraclas et al. 2012).

Pichi also features a number of cognates not included in the 40-member list but common to African and Caribbean AECs. These were first compiled by Smith (1987, 2001) and termed "Ingredient X, Y, and Z". They comprise "Ingredient X" words of African origin (e.g. sosó ‘only’, potวpətว́ 'mud(dy) substance'), "Ingredient Y” words of Portuguese origin (e.g. sàbí 'know', pìkín 'child'), "Ingredient Z” words characterized by particular phonological deviations from their English source forms (e.g. kech 'catch', bwel 'boil') as well as specific function words with diverse origins (nà 'COP/FOC', ùna/ùnu '2PL', dè 'IPFV').

A much smaller percentage of words of mostly West African origin was also inherited from Krio (etymologies from Fyle and Jones 1980). Many of these are tonal words (e.g. okobó 'impotent man' < Yoruba [jkobo] 'impotent man', chàkrá 'destroy, waste' < Fulfulde 'be(have like a) drunk'). The number of words that originate from Bubi, the autochthonous language of Bioko island and the African language with which Pichi has had the longest period of contact is limited to a handful of items in my corpus (e.g. bàta 'buttocks; tòpé 'palm-wine').

Close parallels in grammatical structure provide additional evidence for the relatedness of the African AECs. Figure 1 shows the forms and ordering of TMA markers in four African AECs, namely Krio, Pichi, Nigerian Pidgin (NigP) and Ghanaian Pidgin (GhaP). Forms shared by various constellations of the four languages are marked so by different types of underline. Forms not underlined in any way in the figure (e.g. mek 'SBJV' and dè 'IPFV') are shared by all four languages.

We can see that the form inventory, the positioning of forms relative to the verb and the functions expressed by them are highly similar in the four languages. The most salient commonalities are the presence of the same devices for marking basic TMA categories, represented by the forms without any underline in Figure 1. For example, all four languages have a general imperfective aspect marker dè which covers functions associated with the imperfective domain such as progressive, continuous and habitual. Compare the following two examples from Pichi and Nigerian Pidgin respectively:

(1) À dè smel dì sent fò lèk haw è è dè kuk plàntí. 1SG.SBJ IPFV smell DEF scent ASs like how 3SG.SBJ IPFV cook plantain 'I smell the scent of him cooking plantain.' (Pichi)

(2) À dè wosh plet.

1SG.SBJ IPFV wash dish

'I am washing (the) dishes.' (NigP; Faraclas 1996: 199; gloss adapted) 


\begin{tabular}{|c|c|c|c|c|c|c|c|c|}
\hline Mood & Pron. & Neg. & Tense & Mood & Aspect & & Verb & Aspect \\
\hline mek & yù & no & $\underline{\text { bin }}$ & gò & $\underline{\text { don }}$ & $d \grave{e}$ & chop & finish \\
\hline \multirow[t]{9}{*}{ SBJV } & $2 S G$ & NEG & PST & POT/FUT & PRF & IPFV & 'eat' & COMPL \\
\hline & & & & $\underline{\text { mòs }}$ & $\underline{\text { neva }}$ & kaN/kom & & don \\
\hline & & & & OBL & NEG.PRF & PFV & & COMPL \\
\hline & & & & fò & $\underline{\underline{\text { finis }}}$ & & & \\
\hline & & & & OBL/COND & COMPL & & & \\
\hline & & & & get fò & kin & & & \\
\hline & & & & OBL & НАB & & & \\
\hline & & & & & blànt & & & \\
\hline & & & & & HAB & & & \\
\hline \multirow[t]{2}{*}{ Legend: } & Only & & nly Krio/ & $\underline{\text { Only }}$ & Krio/ & Only Pichi & \multicolumn{2}{|c|}{$\underline{\text { Only }}$} \\
\hline & & & & Pich & i/NigP & & \multicolumn{2}{|c|}{ NigP/GhaP } \\
\hline
\end{tabular}

Fig. 1: TMA form inventory and positioning in African AECs

Another form common to all four languages is kaN/kom, glossed here as "(narrative) perfective" and etymologically related to the verb 'come' (The final capital letter " $\mathrm{N}$ " in kaN indicates that there is a phonologically conditioned variation of [n m] involving the word-final nasal, cf. Yakpo 2009b: 56-58). The distribution and high frequency of this marker in Pichi and in NigP (Tagliamonte 2000) suggests an advanced stage of grammaticalisation into a true perfective marker in these languages, albeit specialised to the high foreground in narrative discourse (cf. Yakpo 2009b: 233-235). In contrast, the distribution of the marker kaN in my GhaP data indicates a more specialised function, namely that of a "consecutive" or "new event” marker (Heine and Kuteva 2002: 69).

Further, the same devices are employed for marking the following mood and tense categories: the potential mood/future tense/irrealis marker gò, the obligative/conditional mood marker fò as well as the subjunctive mood marker cum complementizer mek 'sBJv'.

The major differences between the four languages amount to: (1) the form and positioning of the perfect and completive aspect markers in all four languages; (2) the absence of a dedicated habitual aspect marker in NigP and GhaP as well as the presence of an additional (and less central) habitual marker in Krio (i.e. blànt 'remain; HAB'); (3) the absence of the past tense marker bìn and the 
obligative mood marker mòs in GhaP; (4) the presence of the phrasal obligative modal auxiliary get fò 'have to' (pronounced [gદ́f ’̀]) in Pichi and Krio. NigP and GhaP speakers normally employ the obligative mood marker fò alone for this function.

The differences between the four languages firstly support the split between Krio and Pichi on the one hand, and NigP and GhaP on the other: Only Krio and Pichi feature separately grammaticalized habitual markers (kìn in Krio/Pichi and blànt in Krio). Nigerian Pidgin bridges the gap between Krio/Pichi on one end and Ghanaian Pidgin on the other by featuring forms common to all three languages and no totally distinct forms. NigP shares central markers with Krio/Pichi, namely the past tense marker bìn and the affirmative/negative perfect markers $\mathbf{d} \boldsymbol{\jmath} \mathbf{n} / \mathbf{n} \boldsymbol{\varepsilon}(\mathbf{v}) \mathbf{a}$. At the same time, NigP also shares the feature of a postverbal completive aspect marker finish with GhaP. Examples (3) and (4) below illustrate the differences in perfect and completive marking between GhaP and NigP on the one hand and Pichi on the other. In GhaP and NigP, completive aspect may be expressed via the postverbal marker finish. In GhaP, the use of postverbal finish as shown in the following example, constitutes the only means of overtly expressing a perfective notion next to the use of the bare (dynamic) verb:

(3) Chàlé, yù chop finish?

INTJ 2SG.SBJ eat COMPL

'Man, have you finished eating?' (GhaP)

To my knowledge, Pichi is the only language of the four that only allows the expression of completive aspect by means of preverbal finish (pronounced [fínìs]), as shown in (4). Pichi therefore stands out among the four languages in being the only one without a postverbal completive aspect marker. Further research is needed in order to establish why this is the case.

(4) Chico, yù don finis chop?

INTJ 2SG PRF COMPL eat

'Man, have you (already) finished eating?' (Pichi)

In contrast to Pichi and NigP, Krio marks completive aspect by way of postverbal don rather than finish. The Krio completive aspect marker is therefore homophonous with the preverbal perfect marker and both are presumably derived from English 'done'. Note that both forms may cooccur, as in the following example: 
(5) Olu don it don.

NAME PRF eat COMPL

'Olu has already finished eating.' (Krio; Yillah and Corcoran 2006: 181)

In sum, if we go by the composition of the TMA system alone, a historical scenario is likely in which the Krio input to the three remaining varieties decreases in the order Pichi-NigP-GhaP. Ghanaian Pidgin English exhibits the most idiosyncratic system - there is no grammaticalized past tense marker, habitual aspect marker nor perfect aspect marker. The distinctness of GhaP vis-à-vis the three other languages is therefore primarily defined by the absence of TMA marking devices. Another possible reason for the relative paucity of TMA markers in GhaP is its unique sociolinguistic status as an L2 pidgin and youth sociolect (cf. Dako 2002). In contrast, and contrary to what its appellation might suggest, NigP has enjoyed use as an L1 primary language and full-fledged medium of interethnic communication since at least the $19^{\text {th }}$ century (cf. Faraclas 1996: 2-4). This observation also holds for Pichi and Krio with their substantial L1 communities dating back almost two centuries.

\section{Hybridization}

We have seen that the lexicon, phonology and grammar of Pichi and the other African AECs are very similar. Nevertheless, my experience has been that Pichi sounds very unfamiliar to the ear of a speaker of Nigerian Pidgin, Cameroonian Pidgin, Ghanaian Pidgin English, and even of its Krio forebear. I will go on to show that the particularities of Pichi are a legacy of its isolation from Krio and English and the diverse forms of contact that the language has been subjected to in the course of the past century or so. One of the consequences of this isolation, the absence of postverbal completive aspect marking, has already been described. In the following, I provide further evidence for the divergent path of development of Pichi due to extensive contact and hybridization with Spanish, the colonial and present official language of Equatorial Guinea.

Codemixing is an integral part of the linguistic system of Pichi, and Spanish has left a deep imprint on the lexicon and grammar of the language. In the process, entire semantic fields have been carried over from Spanish into Pichi. For example, Pichi speakers hardly ever employ native, Krio-derived numbers higher than five - my corpus shows that the Pichi numeral seven 'seven' is only employed in $22 \%$ of all possible cases, with the Spanish equivalent siete occurring in all remaining instances. Likewise, the Spanish date nomenclature and system 
of telling the time are the only accepted means of expressing these concepts in Pichi, as shown in (6):

(6) So yù want de de las cuatro, wì don de

so 2SG want BE.AT there the.PL four 1PLPRF BE.AT

$\underline{\text { las }} \underline{\text { tres }} \mathbf{y}$ veinte.

the.PL three and twenty

'So you want to be there at 4 (and) we're already here at 3:20'. (Pichi)

A further consequences of contact with Spanish is the presence of numerous structural calques. One example is the use of the weather verb fol 'to rain'. In the native Pichi (and African AEC) construction, fol takes the weather noun ren 'rain' as a subject, as shown in (7):

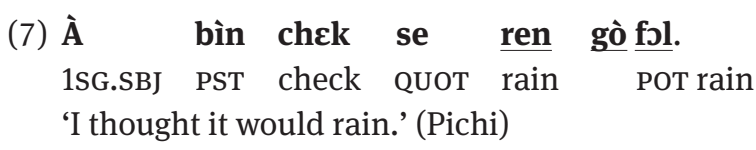

The second, non-native type of construction features the expletive pronoun $\mathbf{e}$ '3SG.SBJ' rather than a weather noun in subject position, as in (8). This construction is a calque from the equivalent Spanish structure in which the verb llover 'to rain' is employed with a (covert) expletive subject as in llueve/está lloviendo '(it) is raining':

(8) À dè si dì de lèke se è è want $\underline{\text { foll. }}$

1SG.SBJ IPFV see DEF day like QUOT 3SG.SBJ want rain

'(The way) I see the weather, it's like it's about to rain.' (Pichi)

There are also indications that contact with Spanish is responsible for the development of a tone-conditioned suppletive allomorphy in the Pichi pronominal system. The allomorphy is conditioned by constraints on syllable structure during the cliticisation of the low-toned 3SG object pronoun =àn (cf. Yakpo 2009b: 68-72 for a detailed treatment). The use of the pronominal allomorph in '3SG.INDP' instead of the conventional clitic object pronoun =àn '3SG.OBJ' serves to avoid an inadmissible sequence of identical (low) tones across the clitic boundary. The allomorphy is distributionally limited though, to instances of vowel hiatus. Vowel-final verbs with a word-final low tone therefore take the object pronoun 
in '3SG.INDP' rather than =àn '3SG.oBJ' as shown with the verb fiba 'resemble' in (9):

(9)

$\begin{array}{llll}\hat{\mathbf{E}} & \mathbf{f i b a} & \mathbf{\text { in }} & \text { bj̀kú. } \\ \text { 3SG.SBJ } & \text { resemble } & \text { 3SG.INDP } & \text { a.lot } \\ \text { 'She resembles him a lot.' (Pichi) }\end{array}$

In contrast, all Pichi verbs with a word-final high tone, cf. (10), as well as those with a word-final consonant take the clitic object pronoun =àn '3SG.oBJ', cf. (11):

(10) Yù dè nyàngá=àn.

2SG IPFV put.on.airs=3SG.oBJ

'You're being ostentatious to him.' (Pichi)

(11) Nà mi lef get=àn.

FOC 1SG.EMP leave get=3sG.OBJ

'It's only me who still has it.' (Pichi)

Tone-conditioned suppletive allomorphy applies to native Pichi verbs like fiba in (9), but on a whole, native verbs with the conditioning feature (a low tone over a word-final vowel) are relatively few in number in my corpus. The toneconditioned allomorphy however applies indiscriminately to all Spanish-derived verbs. This is because the conjugated Spanish 3SG present tense form serves as a conventionalized insertion form for Spanish verbs in Pichi. Due to inflectional characteristics, the 3SG present tense of Spanish verbs always features a wordfinal vowel and bears stress on the penultimate syllable. The vowel-final syllable of 3SG present tense Spanish verbs is interpreted as low-toned by Pichi speakers. Spanish verbs therefore always trigger the tone-conditioned suppletive allomorphy in Pichi as shown in (12), featuring traduce, the 3sG present tense form of traducir 'translate':

\section{(12) Mek à traduce in \\ SBJV 1SG.SBJ translate 3SG.INDP \\ 'Let me translate it.' (Pichi)}

The inflectional feature of a tone-conditioned suppletive allomorphy is unique to Pichi and is not found in other African AECs. In Pichi's ancestor language Krio and in NigP, for example, verbs always take the clitic 3sG.OBJ pronoun =àm irrespective of their pitch configuration. The following two examples from Krio and 
Nigerian Pidgin respectively involve verbs with a word-final low tone, hence verbs that could only take the object/emphatic pronoun in '3sG.EMP' in Pichi:

(13) İ fiba=àm

3SG resemble $=3$ SG.oBJ

'He resembles him/her' (Krio; Njie, p.c.)

(14) À wáya=àm.

1SG bother=3SG.OBJ

'I bothered him/her.' (NigP; Faraclas, p.c.)

I suggest that the development of a tone-conditioned allomorphy in Pichi is contact-induced. I hypothesise that Pichi speakers opted against the use of the clitic 3SG object pronoun =àn with Spanish verbs because they perceived Spanish loan verbs as phonologically and morphologically extra-systemic. Speakers therefore refrained from subjecting Spanish verbs to cliticisation, a morphophonological process associated with the native Pichi layer of the lexicon. As a consequence, speakers recruited the 3SG independent and emphatic pronoun into the system. With the increasing commonness of inserted Spanish verbs, a corresponding phonological rule has been constructed that disallows two successive low tones over two adjacent vowels during the encliticisation of =àn. In this way, tone-conditioned suppletive allomorphy has been extended to Pichi verbs like fiba above, which also feature a word-final, low-toned vowel.

\section{Language shift}

The identification of contact phenomena in Pichi involving Spanish as a donor language poses less of a problem than that involving Bubi, the autochtonous language of Bioko, as a potential donor. One reason for this is the type of contact scenario that is involved in either case (cf. Thomason and Kaufman 1988). Spanish elements are transferred to Pichi via borrowing of matter and patterns (cf. e.g. Matras and Sakel 2007) against the backdrop of a stable Pichi-Spanish multilingualism. In such a maintenance scenario, the recipient language (in our case Pichi) remains vigorous and lexical borrowing is usually far more common than structural borrowing from the donor language (in our case Spanish). The impact of Bubi on Pichi, on the other hand, involves substrate transfer in a situation of language shift. During language shift, contact manifests itself chiefly through structural rather than lexical influence from the shifting community's traditional language (in this case Bubi). 
My observations in Bioko are that there is a substantial and growing group of people with a Bubi cultural background who have shifted or are shifting to Pichi (and Spanish) as their primary language(s) in interactions in and outside of the home. A tendency towards language shift (and loss) has been confirmed by my linguistic consultants from the Bubi community, who unanimously attest to a decreased or largely passive competence in Bubi among the "younger" generations (i.e. somewhere below thirty years of age). Full language shift is probably as yet limited to the capital of Malabo and to Luba, the second largest town of Bioko. In both agglomerations, Pichi has been spoken as a primary language for almost two centuries.

Phonological variation may be drawn upon to identify some of the substrate influence of Bubi on Pichi. This influence is captured by a variation between, roughly, two groups of speakers. Group 1 consists of the Fernandinos, the old commercial and social élite of the island that implanted the ancestor language of Pichi in Bioko and has always used Pichi as its primary community language. Group 1 is also made up of people of diverse ethnic backgrounds who have been accultured into the traditional Fernandino "creole" culture of the capital Malabo. Group 2 generally tends to be made up of younger speakers of up to thirty years of age. This group also tends to be culturally diverse but it is largely made up of speakers with a Bubi cultural background who have adopted Pichi as a primary language (called "nuevos criollos”, i.e. 'new creoles' by Morgades Besari, p.c., 2004) and whose families have been accultured more recently into the Pichispeaking urban culture of Malabo. Group 1 is much smaller than Group 2 and appears to be shrinking at the expense of Group 2 through rural-urban migration from the Bubi speaking country-side of Bioko as well as language shift.

I summarise the most conspicuous features of substrate influence on the phonology of Pichi in what follows. Table 3 provides an overview of variation in the domain of segmental phonology between Group 1 and Group 2 speakers,

Table 3: Phonological variation in Pichi

\begin{tabular}{|c|c|c|c|c|}
\hline & Orthography & Group 1 & Group 2 & Gloss \\
\hline 1. & sut & [ [út] & [sút] & 'shoot' \\
\hline 2. & chench & [tféndz] & [tfént]] & 'change' \\
\hline 3. & ston & [stón] & [tón] & 'stone' \\
\hline 4. & smol & [smól] & [sìmól sùmól] & ‘(be) small’ \\
\hline 5. & help & [hélp] & [hélèp] & 'help’ \\
\hline 6. & stron & [stkón] & [tвว́n] & '(be) strong' \\
\hline 7. & nyus & [jús] & [njús] & ‘(to) use’ \\
\hline 8. & gridin & [grídì] & [grídìn] & '(be) greedy' \\
\hline
\end{tabular}


explanations follow below. The first column of Table 3 provides the orthographic representation of the relevant words used by Yakpo (2009: 51-54, for the rationale behind the orthographic choices). The columns entitled "Group 1" and "Group 2" represent the pronounciation of these words by the two groups characterized above.

Group 2 speakers generally feature fewer segmental phonemic oppositions than Group 1 speakers. The loss of these oppositions appears to have been accelerated within the last two generations or so because they are still fully operative in the speech of older Pichi speakers (roughly above 50 years). Thus, the opposition between the alveolar fricatives [s] and [s] inherited from Krio has been dropped in favour of [s] in all environments (cf. Table 3, example (1)). Likewise, the number of environments in which the affricates $[\mathbf{d} \mathbf{3}]$ and $\left[\mathbf{t} \mathbf{\int}\right]$ are in opposition has been reduced with the voiceless variant gaining ground over the voiced one, cf. (2). It comes as no surprise that most varieties of Bubi do not feature a [ $]$ ] phoneme, while the Bubi varieties spoken in the vicinity of Malabo do not feature a [d3] phoneme either, with [t $\left.\mathbf{\int}\right]$ appearing in all relevant environments (Bolekia Boleká 2008: 69).

Group 2 speakers also manifest a far stronger tendency than Group 1 speakers to simplify consonant clusters by deleting segments, cf. (3). Consonants are also routinely broken up through the insertion of vowels in order to create CV syllable structures as in (4) and (5).

Bubi, faithful to its Bantu phonological orientation is also characterized by a preponderance of CV structures. In fact, Bubi does not feature any consonant clusters to the exception of geminated consonants, and prenasalized and aspirated obstruents (Bolekia Boleká 2008: 57ff.). Bubi also only allows syllable-final vowels and alveolar and bilabial nasals. This corresponds to the Group 2 rendition of the velar nasal [n] as an alveolar [n] (cf. (6)). The Bubi restrictions on wordfinal codas may also be responsible for generalization of the nasalization of the front vowel [i] (and/or insertion of the nasal [n]) in word-final position (cf. (7)), and the prenasalization of the corresponding glide [j] in the onset of many words (cf. (8). This generalization is presumably based by analogy on the existence of a few items in the original Group 1 phonological system with a final (low-toned) [ì], in which the nasal consonant is always realised as a nasal or a nasalised vowel. Two of these words are, for example, the verbs fisin '(to) fish' and hontin '(to) hunt'.

There are no differences in the pronounciation of the items listed under Group 1 in Table 3 and that of the corresponding words in present-day Krio of Sierra Leone (for an overview of Krio phonology, cf. Fyle and Jones 1980: xix). The differences that have developed in the phonological system of Group 2 are, however quite significant. Not only do the (classes of) words listed in Table 3 sound 
markedly different from Krio when used by Group 2 speakers. They are phonologically also much less English than the equivalent words in Krio and in the other West African AECs. As with other characteristics of Pichi discussed in this article, I suggest that the manifestation of Bubi substrate influence in the phonology of Pichi has been possible due to the absence of normalizing pressures from English as a superstrate.

\section{Koineization}

A final factor that has contributed to the specific linguistic profile of Pichi is contact with other African AECs. Pichi shows traces of koineization due to its history of contact with Nigerian and Cameroonian Pidgin. As mentioned in Section 2, plantation labourers from British colonies of West Africa by far outnumbered the indigenous Bubi and Fernandino populations of the island during the cocoa boom of the early to mid $20^{\text {th }}$ century. Pichi appears to have been affected by some degree of koineization in the wake of these large-scale migratory movements to Bioko. Some parts of the phonology, lexicon and grammar are very likely to owe their characteristics to contact and convergence with AEC varieties spoken by West African labour migrants, and Nigerian Pidgin in particular. I will show that koineization has led to the presence of lexical doublets and has contributed to the leveling of paradigms in Pichi.

The existence of lexical variants like the ones contained in the list in Table 4 suggest borrowing from West African AECs other than Krio. The column "AEC source" lists variants found in Pichi that are not of Krio origin, while the "Krio source" column features Pichi variants of Krio origin. The rightmost column "AEC attested in" provides the potential sources of the items listed in the column "AEC source".

The words in Table 4 may be divided into ones that are not attested in Krio and hence appear to be borrowings from Nigerian or Cameroonian Pidgin, cf. (a), as well as doublets, i.e. words that appear in phonological variants, cf. (b)-(c). In group (b), we find a substantial number of words (I just provide a few here) with a monophtong vs. diphtong alternation $/ \varepsilon / \sim / \mathbf{a j} /$, and in group (c) words with a $/ \varepsilon / \sim /$ / / vowel alternation. With these two groups of words, I assume the variant in the column entitled "Krio source" to be of Krio origin, while the other variant is likely to have been introduced from other West African AECs. I am led to this conclusion because the corresponding AEC forms are either not attested (e.g. pesin 'person') in existing sources on Krio (i.e. Fyle and Jones 1980) or if they are attested, are either rare in Krio (e.g. wok 'walk', stanap 'stand up') or have different or specialized meanings in Krio (e.g. kari 'carry’ vs. k(y)عr ‘carry; bring'). 
Table 4: Sources of lexical doublets in Pichi

\begin{tabular}{|c|c|c|c|c|c|}
\hline & & AEC source & Krio source & Gloss & AEC attested in \\
\hline \multirow[t]{2}{*}{ (a) } & Lexemes & arawn & nia & around & NigP, CamP, GhaP \\
\hline & & kwench & day & die (off) & NigP, CamP \\
\hline \multirow[t]{3}{*}{ (b) } & Doublets & nayt & net & night & NigP, CamP, GhaP \\
\hline & & layk & lek & like & NigP, CamP, GhaP \\
\hline & & drayv & dreb & drive & NigP, CamP, GhaP \\
\hline \multirow[t]{5}{*}{ (c) } & & $\mathrm{n} \varepsilon(\mathrm{v}) \mathrm{a}$, & noba & NEG.PRF marker & NigP, CamP \\
\hline & & pesin & posin & person & NigP, CamP, GhaP \\
\hline & & wok & waka & walk & NigP, CamP, GhaP \\
\hline & & stanap/stanıp & tinap & stand (up) & NigP, CamP, GhaP \\
\hline & & kari & $\mathrm{k}(\mathrm{y}) \varepsilon \mathrm{r}$ & carry, bring & NigP, CamP, GhaP \\
\hline \multirow[t]{2}{*}{ (d) } & & if & if/غ̀f & if & NigP, CamP, GhaP \\
\hline & & gel & $g(y) a l$ & girl & NigP, CamP, GhaP \\
\hline
\end{tabular}

With yet other words, cf. (d), both variants appear to be common in Krio (e.g. if/غ̀f 'if', $\mathbf{g \varepsilon l} / \mathbf{g}(\mathbf{y})$ al) and they have presumably been part of the Krio-derived vocabulary of Pichi from the earliest times. Nonetheless, the use of the variant in the "AEC source" column would have been reinforced by contact with other West African AECs, where these forms are the only ones that exist. Hence, for example, the forms ìf 'if' and $\mathbf{g}(\mathbf{y}) \mathbf{a l}$ 'girl' are, to my knowledge, unknown in NigP, CamP and certainly so in GhaP.

I should point out that the items listed in (b)-(d) in the "Krio source" column display phonological features that have been considered to characterize older layers of the common lexicon of the Afro-Caribbean English Lexifier Creoles. One of these is the presence of a monophtong where the corresponding English etymon features a diphtong (e.g. nayt vs. net). In West Africa, monophtongs in place of diphtongs are only yet found in Krio and its direct offshoots Pichi and Aku. In the Caribbean, monophtongs are also found in the Surinamese creoles, for example in Sranan (e.g. neti 'night', Blanker and Dubbeldam 2005: 174) and Ndyuka (also neti 'night', SIL 2003). The Surinamese creoles, like Pichi, have not been in direct contact with English for many centuries either. The use of diphtongs in the majority of AECs on both sides of the Atlantic therefore seems to have arisen in the course of continuous contact with English, while monophtongs presumably dominated in historically earlier AEC varieties. Krio is an exception because the language still features monophtongs despite two centuries of contact with English. However, Krio is also exceptional in the relatively high prestige it has enjoyed, in serving as the primary language of the Krios, a people that dominated Sierra Leonean society throughout much of its history (cf. Wyse 1989). The 
prestige of Krio and its use as a primary language in more functional domains than other African AECs possibly guarded it against an all too pervasive influence of English, of which a phonological feature like diphtongization would have been a particularly conspicuous symptom. The circumstances summarized above therefore support analyzing the more English-like variants in the "AEC source" column in Table 4 as introductions from the AECs listed in the rightmost columns, and Nigerian Pidgin in particular.

I now move on to the formation of indefinite pronouns in Pichi, a structural area in which language contact during koineization appears to have had a more indirect impact, namely through leveling, possibly compounded through the effects of language shift.

Pichi features a system of indefinite pronoun formation in which (negative) quantifiers combine with generic nouns in order to constitute (negative) indefinite pronouns. The system makes no distinction between 'some' and 'any' indefinites (cf. Haspelmath 1997: 48-52). Hence the equivalent of the concept 'anybody' in negative polarity contexts is expressed by a combination of clausal negation and constituent negation, the latter involving the generic noun posin, as shown in (15). Such clauses are no different from other negative clauses, and the generic noun posin may be replaced by any other common noun, e.g. mòtó 'car':

(15) à

\section{no si no posin/mòtó}

1SG.SBJ NEG see NEG person/car

'I didn’t see anybody/any car.' (Pichi)

In contrast to Pichi, Nigerian Pidgin speakers may make use of the negative/freechoice quantifier eni 'any', as shown in (16). I will argue further below that NigP expressions like enibodi are not formed by phrasal syntax alone, and are therefore not fully transparent either. To my knowledge Pichi is the only African AEC that does not at least allow the optional use of a polarity-sensitive item containing a reflex of English 'any':
(16) à
no si enibodi.
1SG.SBJ NEG see anybody
'I didn’t see anybody.' (NigP; Faraclas 1996: 88; orthography adapted)

The formation of indefinite pronouns in Pichi is highly transparent with all but one opaque, monomorphemic form, namely the negative indefinite pronoun natin 'nothing'. One more form is partially opaque: The noun bodi in the negative indefinite phrase no bodi 'NEG body' = 'nobody' is only rarely attested with 
Table 5: African AEC indefinite pronouns compared

\begin{tabular}{|c|c|c|c|}
\hline & Pichi & Krio & Nigerian Pidgin \\
\hline 'some' & $\begin{array}{l}\text { sòn tin } \\
- \\
\text { sòn posin/man }\end{array}$ & $\begin{array}{l}\text { sj̀m tin/sJm-tin } \\
\text { som-bədi } \\
\text { sj̀n posin/man }\end{array}$ & $\frac{\frac{\text { som-ting }}{\text { sjm-bjdi }}}{\text { sj̀m pesin/man }}$ \\
\hline ‘any’ & - & $\begin{array}{l}\varepsilon n i \text { bədi } \\
\varepsilon n i \text { pəsin/man }\end{array}$ & $\frac{\varepsilon n i-b \jmath d i}{\varepsilon n i \text { pesin/-man }}$ \\
\hline ‘every’ & 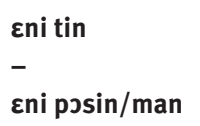 & 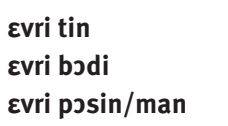 & $\frac{\frac{\varepsilon v r i-t i n g}{\varepsilon v r i-b \jmath d i}}{\varepsilon v r i \text { pesin/man }}$ \\
\hline 'no' & $\begin{array}{l}\frac{\text { natin }}{\text { no bjdi }} \\
\text { no posin/man }\end{array}$ & $\begin{array}{l}\text { natin } \\
\text { no bodi/nómbodi } \\
\text { no posin/man }\end{array}$ & $\begin{array}{l}\text { no ting } \\
\text { no-bodi } \\
\text { no pesin/man }\end{array}$ \\
\hline
\end{tabular}

the meaning 'body' outside of this phrasal expression (the more current term for 'body' is skin). Instead, the fully transparent negative indefinite phrases no man 'NEG man' and no posin 'no person' are far more frequently employed for rendering 'nobody' in Pichi.

The following table lists 'some', 'every', 'any' and 'no' (negative) indefinites for the semantic concepts PERSON (rendered by posin 'person', man 'man' and bodi 'body') and THING (tin(g) in Krio (Fyle and Jones 1980; Hancock 1976), Pichi and Nigerian Pidgin (Faraclas 1996). Opaque and irregular forms are underlined.

The form inventories in Table 5 suggest that Pichi has the most transparent and regular system of indefinite pronoun formation of the three languages. In comparison to Pichi, the paradigm of indefinite and negative indefinite pronouns in Krio is more opaque: In addition to natin, Krio also features the two tonally irregular compound forms șm-tin (instead of s̀̀m tin) and som-bodi (instead of sòm bodi) in which the low-toned quantifier sòm is prosodically integrated into the pronoun and treated like the high-toned initial syllable of a trisyllabic word. The form nómbodi 'nobody' is also more opaque than Pichi no bodi. This Krio form, obviously formed in analogy to som-bodi, features the opaque element *nom-, which has no independent meaning in the language. Additionally, the Krio system manifests a 'some' vs. 'any' split.

The form inventory of NigP also features idiosyncratic forms. Hence som-ting is a compound, with the same prosodic characteristics as its Krio equivalent. Beyond that all forms in the table featuring bodi 'body' as a component are irregular in NigP because they involve a tonal variant (i.e. bodi with a high-low tone pattern) of the common noun bj̀dí (with a low-high tone pattern). Hence these 
forms are not formed by phrasal syntax alone but involve tonal derivation or lexicalisation. It is very likely that the hyphenated compound forms in Krio and Nigerian Pidgin have been substantially influenced by English. For, these compounds reflect the prosodic structure of corresponding English compound forms like nothing, everything, anything something or somebody, which all bear primary stress on the initial syllable.

All in all, the formation of indefinite pronouns is strikingly regular in comparison with that of its West African sister languages. The exceptional status of Pichi in this regard probably has multiple causes. One possible explanation is that the Krio ancestor of Pichi had a similar system in the early $19^{\text {th }}$ century and that Krio only developed a more opaque system later, through contact with English. Another possible explanation is that the acquisition by Pichi of a large number of new speakers in more recent times could have led to substrate effects similar to those identified in the phonology of Pichi. The absence of detailed up-to-date descriptions of Bubi grammar however makes this claim difficult to validate, inspite of its intuitive appeal. Finally, the system could have been leveled through koineization during the cocoa plantation era of the $20^{\text {th }}$ century, when speakers with differing levels of previous exposure to a large variety of African AECs congregated on Bioko. Since a direct English (and Krio) influence on Pichi had been absent since at least the late $19^{\text {th }}$ century, the forces of leveling could unfold themselves fully. The continuing absence of English until today has allowed the stabilization of a rather "un-English", and in comparison with other AECs, exotic pattern of indefinite pronoun formation in Pichi.

\section{Conclusion}

Pichi has many characteristics in common with the other English Lexifier creoles of West Africa. Amongst these are a common lexical core and a TMA system featuring a large overlap of functional elements. Other common features not covered in detail in this article are the use of lexical and morphological tone, a largely isolating structure combined with a small component of bound morphology, predominantly prenominal determination, a weak verb-adjective distinction and the use of serial verb constructions. Many of these structural characteristics fit well within the general areal typology of West Africa (cf. e.g. Faraclas 1988 for a systematic survey).

Notwithstanding these commonalities, Pichi is, in a sense, a wayward daughter, for the language has also developed a very distinct character due to a unique socio-historical constellation: English has been absent for at least a century and a half from the linguistic environment in which Pichi is spoken; Spanish 
has been a superstrate language for approximately the same period of time; Pichi has been acquiring new native speakers through language shift at a rather fast pace, and these have come to outnumber the original creole community of Bioko; the island of Bioko witnessed a massive presence of speakers of other African AEC varietes, and of Nigerian Pidgin in particular, during a period of more than half a century. These circumstances provided the backdrop to contact-induced developments of considerable amplitude in Pichi, involving mixing and hybridization with Spanish, substrate influence from Bubi and koineization involving other African AECs. The outcome is a language that is farther removed from its West African sister languages in terms of its phonology, lexicon and grammar than the other languages from each other.

The distinct trajectory of Pichi makes the language a suitable candidate for the study of a number of phenomena. The notion of the creole continuum (e.g. Rickford 1987) is usually adduced in order to explain language change of a creole in its interaction with the lexifier-superstrate. In the case of Pichi, the absence of contact with its English lexifier makes it possible to investigate the dynamics of internally motivated and contact-induced change without the constant "background noise" from English that characterizes the contact scenario of other AECs. The long separation from English and its Krio forebear might also allow us to identify early, possibly pan-Atlantic features that may have not survived the continuum-type contact of Krio with English in Sierra Leone, or Nigerian Pidgin with English in Nigeria. The comparison of contact between Pichi and Spanish with contact involving other AECs and their non-lexifier superstrates (e.g. Limón Creole English, which also has a Spanish superstrate; cf. e.g. Murray 1974; Winkler 1998) may also increase our understanding of this particular type of contact situation and the linguistic changes that they produce.

Finally, the study of Pichi presents an opportunity to observe the effects of language shift and substrate transfer in a linguistically more homogenous environment than is often the case in other West African contact scenarios. In Bioko, the shifting group largely comes from one language background, namely Bubi. Further, with Bubi being a Bantu language, the typological profile of the substrate is quite different from that of substrates in shift situations involving other West African AECs (e.g. Igbo and other Benue-Congo languages in Southern Nigeria or Temne, Mende and other Westatlantic and Mande languages in Sierra Leone), and we should therefore expect correspondingly different substrate effects as well. The study of Pichi and its comparison with other West African AECs therefore allows us to gain fresh insights into the genesis of the West African AECs. It also offers unique possiblities for understanding the role that language contact has played in the differentiation of the entire family of Afro-Caribbean English lexifier Creoles. 


\section{Abbreviations}

$\begin{array}{ll}\text { ABL } & \text { abilitive mood marker } \\ \text { AEC } & \text { Afro-Caribbean English Lexifier Creole } \\ \text { ASS } & \text { associative preposition } \\ \text { BE } & \text { identity copula } \\ \text { BE.AT } & \text { locative-existential copula } \\ \text { COND } & \text { conditional mood marker } \\ \text { CPD } & \text { compound component derived by tone deletion } \\ \text { EMP } & \text { emphatic (element) } \\ \text { FOC } & \text { focus marker and identity copula } \\ \text { GHAP } & \text { Ghanaian Pidgin English } \\ \text { HAB } & \text { habitual marker } \\ \text { INDP } & \text { independent personal pronoun } \\ \text { IPFV } & \text { imperfective aspect marker } \\ \text { LOC } & \text { general locative preposition } \\ \text { NEG } & \text { negative (particle) } \\ \text { NIGP } & \text { Nigerian Pidgin } \\ \text { OBJ } & \text { object } \\ \text { OBL } & \text { obligative mood marker } \\ \text { PFV } & \text { narrative perfective marker } \\ \text { PL } & \text { plural } \\ \text { POT } & \text { potential mood marker } \\ \text { PRF } & \text { perfect tense-aspect marker } \\ \text { Pron. } & \text { personal pronoun } \\ \text { PST } & \text { past tense marker } \\ \text { Q } & \text { content question particle } \\ \text { QUOT } & \text { quotative marker } \\ \text { RED } & \text { reduplicated element in reduplication } \\ \text { REP } & \text { repeated word in repetition } \\ \text { SBJV } & \text { subjunctive marker } \\ \text { SG } & \text { singular } \\ \text { SP } & \text { sentence particle } \\ \text { SVC } & \text { serial verb construction } \\ \text { TMA } & \text { tense-mood-aspect } \\ & \end{array}$




\section{References}

Aceto, Michael. 1999. The Gold Coast contribution to the Atlantic English Creoles. In: Magnus Huber and Mikael Parkvall (eds.), Spreading the Word: The issue of diffusion among the Atlantic Creoles, 69-80. London: University of Westminster Press.

Alleyne, Mervyn C. 1980. Comparative Afro-American: An historical-comparative study of English-based Afro-American dialects of the New World. Ann Arbor: MI.

Baker, Philip. 1999. Investigating the origin and diffusion of shared features among the Atlantic English Creoles. In: Philip Baker and Adrienne Bruyn (eds.), St. Kitts and the Atlantic Creoles, 315-364. London: Battlebridge.

Baker, Philip and Magnus Huber. 2001. Atlantic, Pacific, and world-wide features in English Lexifier contact languages. English World-Wide 22(2). 157-203.

Blanker, J. C. M., and J. Dubbeldam. 2005. Prisma woordenboek Sranantongo. Utrecht: Spectrum.

Bolekia Boleká, Justo. 2008. Lingüística bantú a través del bubi. Salamanca: Ediciones Universidad de Salamanca.

D’jačkov, M.B. 1981. Jazyk Krio [The Krio language]. Moscow: Izdat’jelstvo Nauka.

Dako, Kari. 2002. Student Pidgin (SP): The language of the educated male elite. Research Review NS 18(2). 53-62.

Del Molino, A. Martin. 1993. La ciudad de Clarence. Malabo: Ediciones Centro Cultural Hispano-Guineano.

Devonish, Hubert. 1989. Talking in tones: A study of tone in Afro-European Creole languages. Kingston: Caribbean Academic Publications.

Devonish, Hubert. 2002. Talking rhythm stressing tone: The role of prominence in Anglo-West African Creole languages. Kingston: Arawak Publications.

Faraclas, Nicholas G. 1988. Nigerian Pidgin and the languages of Southern Nigeria. Journal of Pidgin and Creole Languages 3(2). 77-97.

Faraclas, Nicholas G. 1996. Nigerian Pidgin. London: Routledge.

Faraclas, Nicholas. 2004. Nigerian Pidgin English: Morphology and syntax. In: Bernd Kortmann, Kate Burridge, Rajend Meshtrie, Edgar Schneider, and Clive Upton (eds.), A handbook of varieties of English: 2, 828-853. Berlin: Mouton de Gruyter.

Faraclas, Nicholas, Micah Corum, Rhoda Arrindell, and Jean Ourdy Pierre. 2012. Sociétés de cohabitation and the similarities between the English lexifier Creoles of the Atlantic and the Pacific: The case for diffusion from the Afro-Atlantic to the Pacific. In: Nicholas Faraclas (ed.), Agency in the Emergence of Creole Languages: The role of women, renegades, and people of African and indigenous descent in the emergence of the colonial era creoles, 149-184. Amsterdam: John Benjamins.

Fyfe, Christopher. 1962. A History of Sierra Leone. Oxford: Oxford University Press.

Fyle, Clifford and E.D. Jones. 1980. A Krio-English dictionary. Oxford: Oxford University Press. García Cantús, M. Dolores. 2006. Fernando Poo: una aventura colonial español, Vol I: Las islas en litigio: entre la esclavitud y el abolicionismo, 1777-1846. Barcelona: Ceiba Ediciones. Hancock, Ian. 1976. Krio. Privately circulated manuscript. Austin: University of Texas.

Hancock, lan. 1986. The domestic hypothesis, diffusion and componentiality: An account of Atlantic Anglophone creole origins. In: Pieter Muysken and Norval Smith (eds.), Substrata versus universals in creole genesis, 71-102. Amsterdam: John Benjamins. 
Hancock, Ian. 1987. A preliminary classification of the anglophone Atlantic Creoles, with syntactic data from thirty-three representative dialects. In: G. G. Gilbert (ed.), Pidgin and Creole Languages, 264-334. Honolulu: University of Hawaii,

Heine, Bernd and Tania Kuteva. 2002. World lexicon of grammaticalization. Cambridge: Cambridge University Press.

Haspelmath, Martin. 1997. Indefinite pronouns. Oxford: Oxford University Press.

Huber, Magnus. 1999. Ghanaian Pidgin English in its West African context. Amsterdam: John Benjamins.

Huber, Magnus. 2013. Ghanaian Pidgin. In: Susanne Michaelis, Philippe Maurer, Martin Haspelmath and Magnus Huber (eds.), The atlas of Pidgin and Creole language structures (APiCS). Oxford: Oxford University Press.

Finney, Malcolm Awadajin. 2011. Krio (Sierra Leone Creole). In: Bernd Kortmann and Kerstin Lunkenheimer (eds.), Electronic world atlas of varieties of English. Leipzig: Max Planck Institute for Evolutionary Anthropology. http://www.ewave-atlas.org (accessed 14 May 2013).

Ihemere, Kelechukwu Uchechukwu. 2006. A basic description and analytic treatment of noun clauses in Nigerian Pidgin. Nordic Journal of African Studies 15(3). 296-313.

Lewis, M. Paul, Gary F. Simons, and Charles D. Fennig (eds.), 2013. Ethnologue: Languages of the world. (17th edition). Dallas: SIL International. http://www.ethnologue.com (accessed 11 May 2013).

Lipski, John. 1992. Pidgin English usage in Equatorial Guinea (Fernando Poo). English WorldWide 13(1). 33-57.

Lynn, Martin. 1984. Commerce, christianity and the origins of the 'Creoles' of Fernando Po. Journal of African History 25(3). 257-278.

Magbaily Fyle, C. 2004. The Yoruba diaspora in Sierra Leone's Krio society. In: Toyin Falola and Matt D. Childs (eds.), The Yoruba diaspora in the Atlantic world, 366-382. Bloomington: Indiana University Press.

Matras, Yaron and Janette Sakel (eds.). 2007. Grammatical borrowing in cross-linguistic perspective. (Empirical Approaches to Language Typology 38). Berlin: Mouton de Gruyter.

McWhorter, John. 1997. It happened at Cormantin: Locating the origin of the Atlantic Englishbased Creoles. Journal of Pidgin and Creole Languages 12(1). 59-102.

Murray, Fernando Wright. 1974. Limón Creole: A syntactic analysis. San José: University of Costa Rica PhD dissertation.

Rickford, John. 1987. Dimensions of a creole continuum. Stanford: Stanford University Press.

SIL. 2003. Aukan - English Interactive Dictionary. http://www-01.sil.org/americas/suriname/Aukan/Aukan.html (accessed 11 May 2013).

Smith, Norval. 1987. The genesis of the Creole languages of Suriname. Amsterdam: University of Amsterdam Ph.D dissertation.

Smith, Norval. 2001. Reconstructing Caribbean plantation Pidgin English. Unpublished paper.

Sundiata, Ibrahim K. 1990. Equatorial Guinea: Colonialism, state terror and the search for stability. Boulder: Westview Press.

Tagliamonte, Sali A. 2000. The story of 'kom' in Nigerian Pidgin English. In: John McWhorter (ed.), Language change and language contact in pidgins and creoles, 353-382.

Amsterdam: John Benjamins.

Thomason, S.G. and T. Kaufman. 1988. Language contact, creolization, and genetic linguistics. Berkley: University of California Press. 
Wichmann, Søren, André Müller, Viveka Velupillai, Cecil H. Brown, Eric W. Holman, Pamela Brown, Sebastian Sauppe, Oleg Belyaev, Matthias Urban, Zarina Molochieva, Annkathrin Wett, Dik Bakker, Johann-Mattis List, Dmitry Egorov, Robert Mailhammer, David Beck, and Helen Geyer. 2010. The ASJP Database. (Version 13). http://email.eva.mpg.de/ wichmann/languages.htm (accessed 10 May 2013).

Wichmann, Søren and Matthias Urban. 2012. Towards an automated classification of Englishes. In: Terttu Nevalainen and Elizabeth Closs Traugott (eds.), Handbook on the history of English: Rethinking Approaches to the History of English, 676-686. Oxford/New York: Oxford University Press.

Winkler, Elizabeth Grace. 1998. Limonese Creole: A case of contact-induced language change. Bloomington: Indiana University PhD dissertation.

Wyse, Akintola. 1989. The Krio of Sierra Leone: An interpretive history. London: C Hurst and Co Publishers.

Yakpo, Kofi. 2009a. Complexity revisited: Pichi (Equatorial Guinea) and Spanish in contact. In: Nick Faraclas and Thomas Klein (eds.), Simplicity and complexity in Creoles and Pidgins, 183-215. London: Battlebridge.

Yakpo, Kofi. 2009b. A grammar of Pichi. Nijmegen: University of Nijmegen PhD dissertation. http://webdoc.ubn.ru.nl/mono/y/yakpo_k/gramofpi.pdf (accessed 11 May 2013).

Yakpo, Kofi. 2010. Gramática del Pichi. Barcelona: Ceiba Ediciones.

Yakpo, Kofi. 2012. Betwixt and between: Causatives in the English-lexicon creoles of West Africa and the Caribbean. In: Jaako Leino and Ruprecht von Waldenfels (eds.), Analytical causatives: from 'give' and 'come' to 'let' and 'make', 9-39. München: Lincom Europa.

Yillah, Sorie and Chris Corcoran. 2007. Krio (Creole English). In: John Holm and Peter Patrick (eds.), Comparative Creole syntax: parallel outlines of 18 Creole grammars, 175-198. London: Battlebridge. 
Brought to you by | University of Hong Kong Libraries Authenticated | 147.8.204.164

Download Date | 4/15/14 11:11 PM 